\title{
Building an Administrative Tribunal of an International Financial Institution from Scratch: Lessons from the European Stability Mechanism
}

\author{
David Eatough*
}

\begin{abstract}
This chapter describes the background and decisions that lay behind the creation of the Administration Tribunal of the European Stability Mechanism (ESM) in 2014. It explains the unusual options and policy choices that presented themselves, given that the ESM was established as an international organization with its own treaty. The ESM stands largely outside the European Union's (EU) legal order, under public international law, but operationally must be very closely coordinated with the competent EU institutions to ensure consistency with EU law. The chapter covers the procedural and resourcing issues the ESM resolved with the help of the European Free Trade Association, and its registry, to which the ESM outsourced the forum for oral hearings and registry support. In addition, the chapter touches on the underlying philosophy and aspirations of the ESM human resources and legal functions in the context of ESM's mandate and its desired relationship with a highly professional, expatriate staff. This chapter looks at the needs the ESM sees for other means of dispute resolution for staff and how it is trying to meet these, possible avenues for case management before the relevant tribunal makes its final decision and the current 'multi-forum' situation of the jurisprudence which may adversely influence policy-making.
\end{abstract}

\section{Introduction}

The legal basis and operational context of the European Stability Mechanism (ESM) are perhaps generally not well understood, even within Europe. The ESM is often confused with the institutions of the European Union (EU), or the bilateral sovereign loan facility operated by the European Commission, the European Financial Stability Mechanism. The situation is made even more

* David Eatough, General Counsel and Member of the Management Board, European Stability Mechanism (ESM), d.eatough@esm.europa.eu. 
confusing by the fact that the ESM's predecessor organization, the European Financial Stability Facility (EFSF), is still in existence. ${ }^{1}$ The EFSF is no longer able to lend money and cannot undertake new programmes but it is still a large presence in the international financial markets and continues to be governed as a separate and very different legal entity from the ESM.

This chapter will first explain how the ESM was formed and give some detail on its legal basis. In the context of addressing the formation of ESM's administrative tribunal, this is perhaps particularly important, as the ESM is neither a body nor an agency of the EU, nor a multilateral development bank, nor even a fund like the International Monetary Fund (IMF). Yet the ESM is at the heart of the European Union-being arguably the first de facto institution to be formed by, and for, only those EU member States who participate in its currency union, the countries of the Euro area or 'Eurozone'.

This chapter will rehearse very briefly the historical context for the ESM's formation (Section 2). Next, the interface that this has created - at least for the time being - between the legal framework of the European Union on the one hand, and public international law as it affects other treaty-based international organizations, on the other, will be addressed (Section 3). This will be followed by the choices the ESM made, and the decisions taken in that context, regarding the establishment of the ESM Administrative Tribunal, its Statute and its Rules of Procedure (Section 4). As a past practitioner of national employment law in the United Kingdom (UK), the author will also offer some observations, from their viewpoint as a relative outsider, on getting to grips with the law of the international civil service as the General Counsel of the ESM and the EFSF (Section 5 ).

The sub-prime crisis in the United States in 2008 came immediately before the European financial crisis and there was a European conviction that this was a problem firmly 'Made in America.' ${ }^{2}$ However, whatever the truth of that, by 2010 Europe had its own, undeniably home-grown, financial meltdown. Some countries lost market access completely or looked likely to do so, even though they were full EU and Euro area members. The financial markets started speculating that the European currency union could not survive without some of its weaker members leaving and reinstating their own national currencies. ${ }^{3}$

1 ESM, 'EFSF: An Active Issuer'.

2 Cossu-Beaumont and others 2015, 179.

3 Dabrowski 2019, 131. 
So, the EFSF was set up as a 'temporary' firewall in June 2010. From a design point of view it was a far cry from an international organization made by treaty. Instead, it was an 'off the shelf' special purpose vehicle, formed under Luxembourgish company law, with very limited capital, and a staff of seven. All the same rights and obligations rested upon its directors and employees as in any other private company in that country. There were no privileges and immunities. It then borrowed in huge size on the international capital markets under sovereign guarantees provided by its shareholders, the Euro area member states. This money was the cash that formed the funds made available for similarly large loans to those countries that required this 'backstop' facility. The EFSF still exists as a legal entity today and continues to be a big issuer of bonds, but it can no longer make new loans. ${ }^{4}$

Then, in 2011, the ESM was planned as the successor to the EFSF. However, the finance ministers of the Euro area decided that it was impossible to establish the ESM under the EU treaties. ${ }^{5}$ There was simply no time. Quite apart from the preparation, negotiation and drafting, the required treaty revisions would have led to referendums in some countries. The ESM therefore was established under its own treaty, as an independent international organization, much like the IMF. A link was added to the EU legal framework by the addition of a new sub-paragraph (3) to Article 136 of the Treaty on the Functioning of the European Union (TFEU). ${ }^{6}$ This states that the countries of the Euro area are free to set up their own stability mechanism, to be activated if indispensable to safeguard the stability of the euro area as a whole. It is a permanent solution for a problem that arose early in the sovereign debt crisis: the lack of a backstop for Euro area countries no longer able to tap the markets. The EFSF and ESM remain separate legal entities but share staff, facilities, and operations. Together, the EFSF and the ESM have a $€_{1,00 o}$ billion balance sheet, ${ }^{7}$ and have disbursed $€_{295}$ billion to five Euro area member states. ${ }^{8}$

There is a significant EU tradition of initial intergovernmental arrangements being a transition state towards integration within the EU legal framework. Examples are Schengen, ${ }^{9}$ the Prüm Convention, ${ }^{10}$ and the Social Policy 
Agreement." These all started life as treaties or agreements outside the EU legal framework and all have now been brought wholly or partially within it. Another such transitional example, signed in the same year as the ESM Treaty in 2012, is the Treaty on Stability, Coordination and Governance in the Economic and Monetary Union (TSCG ). ${ }^{12}$ The TSCG was established as an international treaty, binding all EU member states barring Croatia, the Czech Republic and the UK. Accession by Croatia and Czech Republic is pending. The UK took the decision in 2012 not to accede. The TSCG is intended to strengthen the 'economic pillar' of the economic and monetary union, according to its own Article 1, and was established after the financial crisis. It aims, among other things, to foster stricter fiscal discipline and enhance economic policy coordination. Although it is a separate treaty, the TSCG establishes strong links and makes many references to EU law and EU entities, as well as to the ESM. By acceding to the TSCG, Euro area member states have taken on obligations that extend beyond their obligations under the present EU Treaties. The TSCG itself foresees, by Article 16, that its substance will become part of the EU legal framework.

We should therefore see the ESM in its proper evolutionary legal context. The ESM's Managing Director has stated on many occasions that they fully expect the ESM to become part of the EU legal order in due course and with its own enabling amendments to EU primary law. ${ }^{13}$

So, how does this affect the ESM regarding its employment law system and means of redress for ESM staff? There are, of course, three well-recognized systems or 'families' of international civil service rules. These are the UN Common System; the Civil Service System of the EU; and the Civil Service System of the Coordinated Organizations. Then there is perhaps a fourth category into which, by default, the Esm falls. This family is what Gerhard Ulrich has described as the 'Mixed (hybrid) civil service system.'14 None of us, however,

11 Agreement on Social Policy (which went back to the Joint Agreement of the Social Partners of ${ }_{31}$ October 1991, was annexed to Social Policy Protocol of the Treaty of Maastricht 1992 and became a revised Social Chapter of the EC Treaty by the Treaty of Amsterdam 1997).

12 Treaty on Stability, Coordination and Governance in the Economic and Monetary Union.

13 Regling, 30 September 2019.

14 Ullrich 2019, 45. 
operates in a vacuum, and, as Ulrich points out, within this quite disparate group of mostly smaller international organizations, there are discernible blocks which have similar staff regulations driven by the functional similarity of their work and mission. As is also apparent from Schermers and Blokker's extensive comparative work set out in their 'International Institutional Law', there is some "unity within diversity" and indeed, as those authors also say in that work, and notwithstanding the title of this chapter, there is actually no such thing for a new international organization as truly 'starting from scratch.' ${ }^{15}$ One of the things which Ulrich says in his book is that he hopes that it will contribute to the development of more unity, in this family of civil service rules. ${ }^{16}$ This would be particularly beneficial when it comes to the jurisprudence created by our various tribunals and this point will be addressed later.

\subsection{The Incompatibility of the Existing Civil Service Tribunals with the ESM}

The first decision point for the ESM in establishing a dispute resolution mechanism for its staff was whether to ask one of the tribunals for an existing system of civil service law to take jurisdiction. Given the ESM's location, mission, and shareholders, could it ask this of the Civil Service Tribunal of the EU? In formulating the first version of its staff rules, the ESM was necessarily outside the EU Staff Regulations itself, and indeed, it made a virtue of that necessity in a number of ways. One of the most relevant and important in the present context is ESM's ability to hire staff from anywhere in the world rather than being restricted to nationals of its member States. ${ }^{17}$ Nevertheless, the ESM considered that it would be natural to ask the Civil Service Tribunal of the EU (as it then was) to take jurisdiction over its staff cases. This was also certainly the view of several of the member States.

The legal basis of the competence of the EU Civil Service Tribunal (which has recently been subsumed into the General Court) is Article 270 of the TFEU which states that " $[t]$ he Court of Justice of the European Union shall have jurisdiction in any dispute between the Union and its servants within the limits and under the conditions laid down in the Staff Regulations[...]".18 The ESM does not fit into this provision. Indeed, the Commission wrote the ESM in 2014 to say that there was simply no precedent for an attribution of competence to the EU Courts for disputes concerning the staff of an international organization

\footnotetext{
15 Schermers and Blokker 2018, 47.

16 Ullrich 2019, 45.

17 ESM, Safeguarding the Euro in Times of Crisis 2019, 183.

18 Treaty on the Functioning of the European Union, art 270.
} 
like the ESM. The ESM suggested concluding an agreement with the EU itself for access to the court for its staff, but the Commission pointed to the 'closed' categories of possible agreements with international organizations or third countries contemplated in Article 216 of the TFEU. This states that the EU may conclude an agreement with international organizations where the EU Treaties so provide or where the conclusion of an agreement is necessary in order to achieve, within the framework of the Union's policies, one of the objectives referred to in the Treaties, or is provided for in a legally binding Union act or is likely to affect common rules or alter their scope. Again, the Commission view was clear that this excluded such an agreement with the ESM. The other possibility was the Administrative Tribunal of the International Labour Organization (the ILOAT), but this was ruled out on the grounds that, at the time at least, it appeared to be already overburdened with pending cases and the ESM's staff regulations were too different in character from those with which it was familiar.

\subsection{The Establishment of the ESM Administrative Tribunal}

The incompatibility of any existing civil service tribunal left the ESM with the necessity of creating its own. Quite apart from it being the right thing to do, not having an independent administrative tribunal at all would, of course, have exposed the ESM to the possibility of national courts taking jurisdiction, itself a threat to our privileges and immunities, in view of Article 6(1) of the European Convention on Human Rights (ECHR). This states that "in the determination of his civil rights and obligations or of any criminal charge against him, everyone is entitled to a fair and public hearing within a reasonable time by an independent and impartial tribunal established by law". In the key judgment of the European Court of Human Rights (ECtHR) in the 1999 case of Waite and Kennedyv Germany, the ECtHR recalled that the rights set out under Article 6(1) of the ECHR are not absolute, but could be subject to limitations. The Court said that it must be satisfied that any such limitations did not restrict or reduce the access left to the individual in such a way, or to such an extent, that the "very essence" of the "right to a court" was impaired. ${ }^{19}$

Furthermore, any limitation would not be compatible with Article 6(1) if it did not pursue a legitimate aim and if there were not a "reasonable relationship of proportionality between the means employed and the aim sought to be achieved". ${ }^{20}$ The ECtHR's key finding for present purposes is that, a "material factor" in determining whether granting the European Space Agency immunity

19 ECtHR, Waite and Kennedy 1999, para 59.

20 Ibid, para 59. 
from the jurisdiction of German courts was permissible under the Convention was "whether the applicants had available to them reasonable alternative means to protect effectively their rights under the Convention". ${ }^{21}$ In Stichting Mothers of Srebrenica and Others $v$ The Netherlands, the ECtHR stepped back from the automatic contingency between jurisdictional and alternative means by ruling that "no such alternative means existed either under Netherlands national law or under the law of the United Nations. It does not follow, however, that in the absence of an alternative remedy the recognition of immunity is ipso facto constitutive of a violation of the right of access to a court". ${ }^{22}$

The task therefore faced was how to build such a reasonable alternative means to protect the rights of staff while remaining within very tight budget constraints and being proportional to the ESM's small size. A dedicated ESM staff tribunal implied significant initial and ongoing costs, plus the issue of providing for a forum for hearings and securing administrative support for the handling of the pleadings and court documents. The ESM was designed as an organization which could be scaled up or down easily. Many staff were, and still are, recruited on fixed term contracts and many fully expect to go back to their career elsewhere, usually in their home country, after a spell with the ESM in Luxembourg. But apart from this, the key to scalability in the operational design was that a high proportion of the ESM's internal functions were outsourced. The same logic was therefore applied to the formation of the Esm's very own administrative tribunal (the ESMAT).

Once its decision-making bodies had settled on this option of an administrative tribunal purely for ESM staff cases, sceptical questions were asked in the European Parliament. One particular Member of the European Parliament (MEP) went so far as to say that a tribunal for just 100 people (the ESM's total staff at the time) was "contrary to the principle of good administration and the appropriate use of public finances". ${ }^{23}$ Other MEPs seemed to agree that it was "manifestly disproportionate". ${ }^{24}$ The consensus seemed to be that instead of establishing its own tribunal, the ESM could have used the Civil Service Tribunal of the EU as the obvious and efficient solution. Yet, what MEPs missed, at least at first, (aside from permission to adhere to the EU Civil Service Tribunal had already been refused) was that this was to be conceived as an efficient procurement exercise. Experienced judges responded to public tendering and jurists were selected according to rigorous standards overseen by a panel which

\footnotetext{
21 Ibid, para 68.

22 ECtHR, Stitching Mothers of Srebrenica and Others $v$ The Netherlands 2012, para 164.

23 European Parliament, 'Parliamentary Questions', 5 December 2013

24 Ibid.
} 
included an external member appointed by the chair of the ESM's Board of Governors. ${ }^{25}$ The ESMAT was duly formed of very high quality and experienced judges. ${ }^{26}$ Yet, crucially, there are very few fixed costs associated with this tribunal. Each member of the panel only receives a predetermined, fixed sum, by way of remuneration for each case concluded and on which they sit, together with their reasonable expenses. Accordingly, the costs for the ESMAT are largely proportionate to the number of cases with which it must deal. Finally, Article 17 of the ESMAT Statute provides that should access to the Court of Justice of the EU be granted, the ESMAT will be wound up. ${ }^{27}$ Administrative Tribunal

A further innovation concerned the ESMAT's infrastructure, its registrar support and its physical forum for oral hearings. Rather than invest significant time and money in providing a space for hearings and staff and an IT system capable of receiving and dealing with the filing of pleadings, ESM outsourced this. The provider of all these service to the ESM is the Court of Justice of the European Free Trade Association States (the EfTA Court). After a period of intense and highly constructive negotiation and cooperation, principally with the Registrar of the EFTA Court at the time, Gunnar Selvik, the ESM signed a comprehensive Memorandum of Understanding with the EFTA Court in December 2014. ${ }^{28}$ Importantly, the Registrar role itself is not performed by the EFTA Registrar. That responsibility stays with the ESMAT, but all the services required by the registrar function are fulfilled by the EFTA court using its own resources and staff. Financial compensation, in a fixed amount, was agreed at a very fair and proportionate level and, again, is entirely dependent, after the set-up costs, on the occurrence of actual cases. Perhaps the lesson to be drawn from this, is that necessity is the mother of invention.

In terms of the ESMAT's Statute and Rules of Procedure themselves, there are three notable experiences in the context of the ESM's aim of efficiency and flexibility. ${ }^{29}$ Firstly, although the Statute of the ESM was necessarily drafted as an internal legal department exercise at the start, the ESM involved the full

\footnotetext{
25 Ibid.

26 ESM, 'Composition of the Tribunal'.

27 ESMAT Statute, art 17.

28 EFTA Court, 18 December 2014.

29 Statute of ESMAT; Rules of Procedure of ESMAT.
} 
tribunal in the formulation of the Rules of Procedure and in a complete overhaul of the Statute. This was a very valuable exercise in obtaining exposure to practice elsewhere. In addition, the judges had their own firm views. These included ensuring high standards for access to justice by staff, the timelines involved for filing an appeal, for rendering a judgement, and many others. They very much took the part of the potential litigant in this respect. The ESM was also able to test the procedures by filing an appeal and running through all the administrative actions in a full dry run. Second, the ESM principle of flexibility continued to apply so that more could be added later, if necessary, without trying to second-guess every possible scenario at the outset. Article 28 of the EsMAT Rules of Procedure states that the full tribunal can decide to direct proceedings as they see fit, where nothing is otherwise specifically provided for, and gives very broad guidance on what this could include. Third, encouragement was provided to conclude proceedings quickly, yet always mindful of the Waite and Kennedy $v$ Germany requirement for proportionality. ${ }^{30}$ This included a reference in the Statute to the ESM's mandate and mission, its limited resources and the imperative need to provide time critical interventions. An explicit provision was also included in Article 8(6) to the effect that, unless justified by exceptional circumstances, the tribunal must conclude any appeal within a period of six months following the day it has been validly lodged.

\section{5}

\section{Conclusion}

By way of conclusion, there are some things which are very noticeable to the author as a practitioner from a common-law, national jurisdiction. Some of these are perhaps inevitable, and go with the territory, and include a certain amount of simplification and slimming down of the options and rules of procedure available in a fully-fledged national system of law. Yet, as regards some others, could these be improved upon? Three such observations follow.

The number of important tribunals is not trivial. Each has its own jurisprudence and, of course, this is to a large extent specific to the civil service system or family to which it belongs. Yet, for a risk averse institution, as international organizations tend to be, there is perhaps a multiplication effect of the tribunal decisions that frighten HR departments and decision-makers in our institutions. The reality is that you can often find a tribunal decision which supports 'worst case scenario' thinking as regards a potential staff dispute, whether this is when such a dispute is actually in prospect, or when drafting polices and

3o $\quad$ ECtHR, Waite and Kennedy v Germany v Germany 1999, para 59. 
rules, at least where the law is perhaps not so clear. It may be that they can be distinguished one from the other by lawyers with the relevant knowledge and experience. Nevertheless, the author's experience is that there remains a tendency arising from this situation that the policy direction becomes more risk averse than is really warranted, or than is in the interests of the institution. Solutions to this are not so obvious, but the more one can support and encourage 'unity within diversity' in this crucial aspect the better. ${ }^{31}$

Second, the management of cases and the narrowing down of the issues in dispute in very busy courts, at least in the author's jurisdiction of practice, have been the subject of intense scrutiny and focus in order to improve efficiency. Perhaps one of the leading examples of this, in terms of practical outcomes, is the Commercial Court in London. As one senior practitioner and judge recently put it, "it is not necessarily that it is difficult to make a decision, it is that it is often difficult to work out what needs to be decided - so that is where there is a lot of emphasis". The Commercial Court insists on at least one "Case Management Conference', a 'List of Issues' and an agreed 'Case Summary', with a maximum limit on the length of this last document. ${ }^{32}$ The focus is on disclosure and the key facts in order to produce a crystal clear picture on which the parties can agree and which then provides the judges with the matters requiring their decision - and only those matters. ${ }^{33}$ Of course, one must be mindful of the context of an administrative tribunal, which does not always lend itself to this ultimate degree of case management-especially where the complainant is not represented. Nevertheless, some of these techniques are surely useful. The field of international administrative law certainly does yield one recent example of 'preventive' or 'determinative' and pro-active dispute resolution in perhaps a similar vein or spirit. This is the decision of the Asian Development Bank's (ADB) Administrative Tribunal in 2018 in relation to a broad revision of the ADB's compensation and benefits package which included changes to the education allowances for dependent children of certain of its staff. ${ }^{34}$ The notable feature in this context is not so much the result but the process. The decision was made after the ADB and staff cooperated in order to agree a direct application to the tribunal on behalf of (initially) 106 staff members on a tightly defined series of facts and legal issues. The process seems to have been highly efficient and very much in the category of a collaborative effort to make

$31 \quad$ Schermers and Blokker 2018, 23.

32 Business and Property Court 2019, 14-15.

33 For a flavour of some of these techniques, see ibid, 16-17.

34 ADBAT, Perrin et al. $v$ ADB (No. 3) 2018, paras 1-3. 
sure that the judges only had to decide on the questions, not on what those questions were.

The third observation relates to the tendency for Staff Regulations and Rules in international organizations to increase in length and complexity over time, driven very often by the desire of staff for more clarity in specific situations, on the one hand, and by the need to produce auditable paper trails and blackletter regulatory support for managers in taking decisions. Unfortunately, these completely understandable factors can result in an enormous rule book and a concomitant loss of perspective on the underlying relationship between employer and employee. That relationship should be a joint enterprise, a means to an end, not an antagonistic relationship of legal position taking and constant recourse to rival interpretations of the Staff Regulations and Rules. Having said all that, it is, of course, inevitable that conflicts will arise. Having a toolkit available, which includes, but does not begin and end with, the formal tribunal, is therefore important. The ESM is reviewing its internal procedures for preventing, resolving and adjudicating staff concerns and grievances and the institution has committed considerable resources to make sure that people management training and conflict coaching are both available and actually taken up by staff. This includes guest speaker workshops and diversity training. In addition, the ESM has appointed an external mediation service which can be particularly useful for longer standing grievances that have not otherwise been amenable to an internally brokered solution. Of course, this is only relevant to grievances which do not include breaches of the ESM's Code of Conduct.

Lastly, this gives rise to an aspiration, much easier to articulate than to execute, of course. Nevertheless, aspirations are important. They frame the Esm's policy making and drive its internal culture. The ESM's aspiration is to keep its rule book slim, to keep flexibility high, to minimise the need for litigation and to maintain a healthy relationship of mutual respect and tolerance with the ESM's amazing staff.

\section{Reference List}

Agreement on Social Policy (2 February 1992, annexed to the Protocol on Social Policy of the Treaty of Maastricht on European Union oJ C 191, 29.7.1992, pp. 1-112, and became a revised Social Chapter of the EC Treaty by the Treaty of Amsterdam 1997).

Business and Property Courts, The Commercial Court Report 2017-2018 (Including the Admiralty Court Report) (Judiciary of England and Wales, 2019) <https://www.judi- 
ciary.uk/wp-content/uploads/2019/02/6.5310_Commercial-Courts-Annual-Report_ v3.pdf $>$ accessed 15 November 2019 .

Convention Between the Kingdom of Belgium, the Federal Republic of Germany, the Kingdom of Spain, the French Republic, the Grand Duchy of Luxembourg, the Kingdom of the Netherlands and the Republic of Austria on the Stepping up of CrossBorder Cooperation, Particularly in Combating Terrorism, Cross-Border Crime and Illegal Migration (Prüm Convention) (adopted 27 May 2005, entered into force 1 November 2006) 2617 UNTS 3.

Convention Implementing the Schengen Agreement of 14 June 1985 Between the Governments of the States of the Benelux Economic Union, the Federal Republic of Germany and the French Republic on the Gradual Abolition of Checks at Their Common Borders (Schengen Agreement) (signed 19 June 1990, entered into force 1 September 1993) OJ L 239, 22.9.2000, pp. 19-62.

Cossu-Beaumont L and others (eds), The Crisis and Renewal of American Capitalism: A Civilizational Approach to Modern American Political Economy (1st edn, Routledge 2015).

Dabrowski M, 'The Economic and Monetary Union: Its Past, Present and Future' (European Parliament, January 2019) < https://www.europarl.europa.eu/cmsdata/159703/CASE_final\%2opublication.pdf $>$ accessed 6 March 2020.

EfTA Court, 'Press Release 20/2014: The EfTA Court Registry to Provide Registry Services for the Administrative Tribunal of the European Stability Mechanism (ESMAT)' (EFTA Court, 18 December 2014) < https://eftacourt.int/wpcontent/uploads/2019/01/19_2014_PR_ESMAT.pdf> accessed 4 March 2020.

European Financial Stability Facility, 'Financial Statements, Management Report and Auditor's Report' (EFSF, 31 December 2018) <https://www.esm.europa.eu/sites/default/files/2019-06-26_efsf_fs_2018.pdf > accessed 4 March.

European Parliament, 'Parliamentary Questions' (European Parliament, 5 December 2013) < https://www.europarl.europa.eu/sides/getDoc.do?pubRef=-//EP//TEXT+OQ $+\mathrm{O}-2013-000141+0+\mathrm{DOC}+\mathrm{XML}+\mathrm{Vo} / / \mathrm{EN} \&$ language $=\mathrm{EN}>$ accessed 4 March 2020.

European Stability Mechanism, 'Composition of the Tribunal' (ESM) <https://www .esm.europa.eu/how-we-work/composition-tribunal> accessed 4 March 2020.

European Stability Mechanism, 'EFSF: An Active Issuer' (ESM) <https://www.esm.eu ropa.eu/investors/efsf/efsf-active-issuer $>$ accessed 4 March 2020.

European Stability Mechanism, 'Facts' (ESM) < https://www.esm.europa.eu/> accessed 4 March 2020.

European Stability Mechanism, 'Financial Report' (ESM) <https://www.esm.europa. eu/publications/annual-report-2018/financial-report> accessed 4 March 2020.

European Stability Mechanism, Safeguarding the Euro in Times of Crisis: The Inside Story of the ESM (1st edn, Publications Office of the European Union, 2019).

Perrin et al. $v$ Asian Development Bank (No.3), АDвAт Decision No 113 (2018). 
Regling K, 'Strengthening the ESM and EMU' (Inter-Parliamentary Conference on Stability, Economic Coordination and Governance in the European Union, Helsinki, 30 September 2019)<https://www.esm.europa.eu/speeches-and-presentations/\%E2\% $80 \%$ Cstrengthening-esm-and-emu $\% \mathrm{E} 2 \% 80 \% 9 \mathrm{D}$-speech-klaus-regling $>$ accessed 4 March 2020.

Rules of Procedure of the Administrative Tribunal of the European Stability Mechanism (ESMAT) <https://www.esm.europa.eu/sites/default/files/esmatrulesofproceduredecember2014.pdf $>$ accessed 9 March 2020.

Schermers H G and Blokker N, International Institutional Law: Unity Within Diversity (6th edn, Brill Nijhoff 2018).

Statute of the Administrative Tribunal of the European Stability Mechanism (ESMAT) <https://www.esm.europa.eu/sites/default/files/2016_05_12_esmat_statut.pdf> accessed 6 March 2020.

Stitching Mothers of Srebrenica and Others $v$ The Netherlands App No 65542/12 (ECtHR, 8 October 2012).

Treaty Establishing the European Stability Mechanism (ESM Treaty) (signed 2 February 2012, entered into force 27 September 2012).

Treaty on Stability, Coordination and Governance in the Economic and Monetary Union (signed 2 March 2012, entered into force 1 January 2013).

Treaty on the Functioning of the European Union (signed on 25 March 1957, entered into force 1 January 1958) oJ C 326, 26.10.2012, pp. 47-390.

Treaty of Amsterdam (signed 2 October 1997, entered into force 1 May 1999) OJ C 340, 10.11.1997, pp. 1-144.

Ullrich G, The Law of the International Civil Service: Institutional Law and Practice in International Organisations (Duncker \& Humblot GmbH 2019).

Waite and Kennedy $v$ Germany App No 26083/94 (ECtHR, 18 February 1999). 